\title{
PARTISIPASI PEKERJA DALAM SERIKAT PEKERJA
}

\author{
Hamong Santoso ${ }^{1}$ dan Indi Djastuti ${ }^{2}$ \\ 1 Program Magister Manajemen Fakultas Ekonomi Universitas Diponegoro \\ Jalan Erlangga Tengah Nomor 17 Semarang, Indonesia, Telepon +62-024-8453657 \\ 2 Fakultas Ekonomi Universitas Diponegoro Semarang \\ Jalan Prof. Soedharto Tembalang Semarang, Indonesia, Telepon +62-024-76486851 / +62-024-76486850
}

\section{Diterima 9 Mei 2011 / Disetujui 11 September 2011}

\begin{abstract}
This research aims to evaluation performance of agriculture extension agent and estimates expense of transaction needed to design revitalization scenario of counseling institute. This research applies primary data collected through interviews with respondent and key-persons. 200 farmers and 30 Agriculture extension agents taken as a sample with multistage sampling. The descriptive Statistics applied to depict responder profile, extension agent performance, and condition of the institution of counseling. A transaction cost will be applied to estimate the value of the expense of the transaction needed to design revitalization scenarios of the institution of counseling. The result of the research indicates that the behavior of farming in the research area has not been efficient, so that there is an opportunity to optimize farm production through counseling.
\end{abstract}

Keywords: extension agent performance, transaction cost, counselling institute, farming

\begin{abstract}
Abstrak: Penelitian ini bertujuan mengevaluasi kinerja petuga penyuluh pertanian dan mengestimasi biaya transaksi yang dibutuhkan untuk mendisain skenario lembaga konseling. Penelitian ini menggunakan data primer yang dikumpulkan melalui wawancara dengan para responden dan tokoh masyarakat. Sejumlah 200 orang petani dan 30 orang petugas penyuluh pertanian diambil sebagai sampel dengan metode multistages sampling. Statistik deskriptif digunakan untuk menggambarkan profil responden, kinerja penyuluh pertanian, dan kondisi lembaga konseling. Biaya transaksi diterapkan untuk memperkirakan nilai biaya operasi yang diperlukan merancang skenario revitalisasi lembaga konseling. Hasil penelitian menunjukkan bahwa kinerja pertanian di daerah penelitian tidak efisien dan ada kesempatan mengoptimalkan produksi usaha tani melalui konseling.
\end{abstract}

Kata kunci: kinerja penyuluhan, biaya transaksi, lembaga konseling, usahatani

\section{PENDAHULUAN}

Pembangunan ekonomi bertujuan meningkatkan standar hidup masyarakat. Peningkatan tersebut akan tercapai jika produksi nasional dapat ditingkatkan lebih cepat dari pertumbuhan penduduk. Di samping jumlah produksi ditingkatkan perlu juga diperhatikan tingkat pemerataan agar pertumbuhan ekonomi yang dicapai dapat dinikmati oleh seluruh penduduk. Selama proses pembangunan ekonomi berlangsung dibutuhkan sumber daya dan unsur pen- dukung lainnya, termasuk sumber daya alam, teknologi, dan sumber daya manusia dalam jumiah dan kualitas yang memadai, agar tercipta produktivitas yang tinggi sehingga target pertumbuhan ekonomi dapat tercapai. Dalam pengembangan sumber daya manusia, sudah menjadi kesepakatan umum yang mengatakan bahwa sumber daya manusia merupakan unsur pendukung utama dalam proses pembangunan. Bahkan akhir-akhir ini sumber daya manusia dipandang sebagai unsur yang amat menentukan proses pembangunan, terutama di negara 
berkembang.

Pembangunan nasional yang dilakukan sejak akhir tahun 1970, yaitu pada saat munculnya orde baru diwarnai dengan meningkatnya perekonomian nasional antara lain dengan berkembangnya industrialisasi. Dengan situasi demikian membawa konsekuensi perlunya peningkatan perhatian terhadap sektor ketenagakerjaan, khususnya hubungan industrial dan perlindungan tenaga kerja. Secara makro kondisi ketenagakerjaan di Indonesia kurang menguntungkan, dimana kondisi penyediaan tenaga kerja lebih besar dari permintaan tenaga kerja. Permasalahan ketenagakerjaan makro di Indonesia tersebut akan menjadi lebih sulit karena ditambah dengan permasalahan-permasalahan mikro yang ada di perusahaan.

Masalah ketenagakerjaan yang ada di tingkat perusahaan itu di antaranya adalah persoalan buruh atau pekerja. Persoalan buruh sering dikaitkan dengan tingkat kemiskinan, sehingga pekerja di Indonesia identik dengan upah dan daya beli yang rendah, jam kerja yang panjang, dan tidak memadainya jaminan kesehatan dan keselamatan kerja

Pembahasan tentang pekerja dan permasalahannya tersebut tidak akan terlepas dengan peran dan fungsi dari serikat pekerja. Gerakan serikat pekerja yang ada di Indonesia mempunyai sejarah yang panjang, dimana gerakan ini dimulai sejak abad XIX (1879). Hal ini ditandai dengan lahirnya NIOG (Netherland Onder Werpen Genoottschaft) sebagai serikat pekerja pertama yang mengorganisir guru-guru di sekolah Belanda (Uwiyono, 2000). Selanjutnya disusul dengan lahirnya serikat pekerja - serikat pekerja lain berdasarkan sektor dan profesinya. Pembentukan serikat pekerja di kalangan pekerja Belanda ini telah mendorong terbentuknya serikat pekerja di kalangan pekerja Indonesia. Pada tahun 1908 VSTP (Vereneging Van Spoor en Trem Personeel) serikat pekerja dari kalangan pekerja Indonesia terbentuk (Uwiyono, 2000). Setelah Indonesia merdeka perkembangan serikat pekerja di Indonesia berkembang dengan sangat cepat dan banyak partai politik yang membentuk serikat pekerja dengan tujuan untuk memperkuat posisinya dalam masyarakat. Antara lain Nahdlatul Ulama (NU) membentuk SARBUMUS1, kemudian Partai Nasional Indonesia (PNI) membentuk KBM, Partai Komunis Indonesia (PKI) membentuk SOBSI.

Pada masa Orde Baru, pekerja telah ditata sedemikian rupa oleh pemerintah sebagai akibat hubungan yang kompleks antara pertimbangan-pertimbangan ekonomi dan politik. Artinya kebijakan perburuhan di masa Orde Baru tidak semata-mata dibentuk oleh tuntutan agenda ekonomi pada waktu itu. Pertimbangan-pertimbangan politik pun turut berperan dalam kebijakan tersebut, khususnya mencegah kembali elemen-elemen radikal dalam gerakan buruh dan secara lebih umum untuk membatasi ruang gerak tiap organisasi yang bersifat massal. Hal itu akhirnya betpengaruh juga terhadap gerakan serikat pekerja dimana mereka telah diarahkan untuk mendemobilisasi buruh sebagai kekuatan sosial politik (Hadiz, 1990). Kondisi ini menyebabkan partisipasi pekerja di dalam serikat pekerja sangat rendah, karena segala sesuatu yang berkaitan dengan pekerja telali di tata sedemikian rupa sehingga pekerja harus menerima segala perlakuan dari perusahaan.

Setelah Orde Baru tidak lagi berkuasa kondisi perburuhan di Indonesia tetap belum mengalami kemajuan. Walaupun demikian muncul fenomena baru di dalam hubungan industrial di Indonesia yaitu munculnya serikat pekerja-serikat pekerja baru, yang muncul sebagai akibat ketidakpuasan terhadap serikat pekerja yang ada selama ini (SPSI). SPSI yang sekarang berganti nama menjadi FSPSI (Federasi Serikat Pekerja Seluruh Indonesia) di masa orde baru merupakan alat kontrol dan demobilisasi massa sehingga tidak sesuai dengan harapan. Kegagalan SPSI dalam peningkatan hak-hak asasi manusia dan standar ketenagakerjaan pada masa Orde Baru disebabkan oleh: pertama, faktor internal yang berkaitan dengan struktur atau bentuk organisasi SPSI dan kemandirian SPSI. Kedua. adalah faktor eksternal yang meliputi antara lain peraturan perundangan di bidang ketenagakerjaan, pelaksanaan pola hubungan industrial Pancasila, sikap pengusaha, kondisi ekonomi, situasi politik dan lainlain (Uwiyono, 2000). Lebih lanjut Uwiyono 
(2000) mengatakan, dilihat dari struktur organisasi, SPSI diupayakan terus menerus sebagai wadah tunggal selama masa orde baru, telah memperlemah militansinya sebagai serikat pekerja, sehingga SPSI kehilangan kehilangan fungsi kontrolnya sebagai serikat pekerja. Ketiadaan persaingan antarserikat pekerja memperlemah semangat SPSI untuk memperjuangkan hak-hak anggotanya.

Munculnya keanekaragaman serikat pekerja pada era reformasi ini dimulai dengan pecahnya FSPSI menjadi dua yaitu FSPSI (yang lama) dan FSPSI Reformasi (yang baru), serta munculnya berbagai macam serikat pekerja. Saat ini terdapat 20 serikat pekerja yang terdaftar di Departemen Tenaga Kerja yaitu, SARBUMUSI, KBM, GASBUNDO, FSBDI, PPM1, FOKUBA, FSPSI, FSPSI Reformasi, SBSI, FSPMI, GASPERMINDO, SP Independent, ASPEK Indonesia, ASOKADIKTA, KPNI, KBKI, GSBI, KORPRI, SBMSK, dan FSP BUMN (Uwiyono, 2000). Di samping itu pemerintah juga mendorong terbentuknya serikat pekerja tingkat perusahaan (SPTP), yaitu serikat-serikat pekerja yang bebas (non atiliasi) di tingkat perusahaan. Pemerintah juga mulai memberlakukan Undang-Undang Republik Indonesia Nomor 21 Tahun 2000 Tentang Serikat Pekerja yang mulai berlaku efektif mulai tanggal 4 Agustus 2000 maka segala hal yang berkaitan dengan serikat pekerja, sekarang ini harus menyesuaikan dengan undangundang tersebut. Berlakunya undang-undang tersebut membuka peluang bagi serikat pekerja untuk berperan lebih aktif dalam memperjuangkan kepentingan pekerja. Dengan banyaknya pilihan serikat pekerja, membuat pekerja lebih mempunyai pilihan untuk bergabung dengan serikat pekerja sesuai dengan harapanharapan yang ingin dicapai. Kebebasan untuk memilih tersebut, memungkinkan pekerja untuk dapat berpartisipasi lebih aktif di dalam serikat pekerja

Perubahan yang terjadi sekarang ini adalah, untuk mempertahankan eksistensinya serikat pekerja tidak lagi bisa bergantung pada pemerintah, sehingga penggalangan kekuatan internal organisasi serikat pekerja merupakan satu-satunya jaminan. Hal ini merupakan tantangan bagi serikat pekerja untuk merekrut anggota sebanyak-banyaknya dan meningkatkan partisipasi anggotanya.

Keanggotaan serikat pekerja di Provinsi Jawa Tengah khususnya di Kota Semarang masih sedikit. Hal ini dapat dilihat dari jumlah anggota serikat pekerja yang terdaftar melalui serikat pekerja yang terdaftar di Departemen Tenaga Kerja Provinsi Jawa Tengah. Berdasarkan sektor usaha kayu dan hutan terdapat 2.195 orang, Percetakan dan Penerbitan 4.640 orang, Rokok Tembakau Makanan dan Minuman 6.715 orang, KEP 9.540 orang, LEM 5.039 orang, Tekstil Sandang dan Kulit 11.676, Farmasi dan Kesehatan 3.073 orang, Pariwisata 2.231 orang, Transportasi 5.316 orang, serta Niaga dan Bank 786 orang. Jumlah totalnya ada 51.211 orang.

Dari jumlah pekerja yang masuk ke dalam serikat pekerja adalah sebesar 51.211 orang, sedangkan jumlah pekerja yang ada di Kota Semarang adalah sebesar 142.466 orang. Ini berarti hanya sebesar 35,95 persen pekerja yang terdaftar dan berpartisipasi di dalam serikat pekerja. Dengan demikian serikat pekerja harus dapat mengoptimalkan kinerjanya dengan cara meningkatkan partisipasi anggotanya, agar harapan-harapan anggotanya dapat tercapai. Seiring dengan semakin baiknya serikat pekerja melalui partisipasi anggotanya, pada gilirannya serikat pekerja akan dapat menarik anggota baru.

Secara garis besar partisipasi pekerja di dalam serikat pekerja terbentuk karena dua alasan, yang pertama adalah alasan ideologis dan yang kedua adalah alasan-alasan yang bersifat pragmatis seperti ketidakpuasan terhadap manajemen (Simamora, 1997). Menurut Wheleer dan McClenden (1991), ada tiga faktor penting untuk menjelaskan mengapa pekerja berpartisipasi di dalam serikat pekerja yaitu: ketidakpuasan terhadap manajemen, manfaat yang diperoleh (utilitarian), dan kepercayaan politik atau ideologi.

Walaupun alasan politik maupun ideologi sangat jarang untuk dijadikan alasan untuk berpartisipasi di dalam serikat pekerja, akan tetapi di Indonesia hal ini masih cukup relevan sebagai sebagai salah satu faktor yang menyebabkan pekerja berpartisipasi di dalam serikat pekerja. Hal ini disebabkan karena kebijakan 
perburuhan di Indonesia yang tidak hanya dilihat dari aspek ekonomi tetapi juga aspek politik. Kondisi ini adalah sesuatu yang umum terjadi di negara berkembang seperti Indonesia dimana keterlibatan negara dalam proses industrialisasi di dunia ketiga berada dalam posisi yang sangat dominan dan oleh karenanya dapat mempengaruhi sistem hubungan industrial (S.A. Siddique, 1989 hal :390).

Rumusan Masalah. Masalah-masalah yang berkaitan dengan hubungan industrial di Indonesia masih sering terjadi, dan pada saat ini telah banyak lahir serikat pekerja-serikat pekerja baru. Dengan semakin banyaknya serikat pekerja membuat semakin besar tantangan yang dihadapi oleh pihak manajemen maupun serikat pekerja dalam menciptakan sistem hubungan industrial yang harmonis.

Banyaknya serikat pekerja yang muncul sekarang ini, haruslah diimbangi oleh partisipasi pekerja di dalam serikat pekerja. Partisipasi anggota serikat pekerja menjadi sangat penting, karena serikat pekerja pada saat ini merupakan organisasi yang mandiri sehingga hidup matinya suatu serikat pekerja ditentukan oleh serikat pekerja itu sendiri. Untuk itu perlu dilakukan pengkajian masalah faktor-faktor yang mempengaruhi partisipasi pekerja di dalam serikat pekerja dan seberapa besar faktorfaktor tersebut berpengaruh terhadap partisipasi pekerja di dalam serikat pekerja.

Menurut Paul Tolich dan Mark Harcourt (1996, hal: 71) partisipasi pekerja di dalam serikat pekerja dipengaruhi oleh beberapa faktor, yaitu mempunyai masalah dengan kerja, perbaikan upah dan kondisi kerja, percaya terhadap serikat pekerja, sebagian besar pekerja adalah anggota serikat pekerja, memperoleh pelayanan hukum, pelatihan dan keuangan, dan pelayanan profesional.

Tujuan penelitian. Tujuan penelitian ini adalah untuk menganalisis pengaruh faktor ketidakpuasan terhadap manajemen terhadap partisipasi pekerja di dalam serikat pekerja, menganalisis pengaruh faktor manfaat bersama ( $\mathrm{col}$ lective benefits) terhadap partisipasi pekerja di dalam serikat pekerja, menganalisis pengaruh faktor manfaat individu (individual benefits) terhadap partisipasi pekerja di dalam serikat pekerja dan menganalisis pengaruh faktor kepercayaan politik atau ideologi terhadap partisipasi pekerja di dalam serikat pekerja. Selain itu juga perlu dianalisis secara bersama-sama pengaruh variabel ketidakpuasan terhadap manajemen, manfaat bersama, manlaat individu, dan kepercayaan politik atau ideologi terhadap partisipasi pekerja di dalam serikat pekerja

Hasil temuan dari penelitian ini dari segi ilmiah diharapkan dapat memberikan wawasan baru bagi akademisi di bidang sumber daya manusia, khususnya pada bidang hubungan industrial di Indonesia. Selain itu, dari segi praktis, diharapkan dapat memberikan masukan bagi serikat pekerja, pihak manajemen maupun lembaga lain yang terkait tentang seberapa jauh faktor-faktor yang dijadikan alasan pekerja untuk berpartisipasi di dalam serikat pekerja berpengaruh, terutama di dalam kebijakan-kebijakan yang berkaitan dengan pekerja.

Partisipasi di dalam Serikat Pekerja. Hubungan perburuhan (labor relations), adalah hubungan berkesinambungan di antara sekelompok karyawan (yang diwakili oleh serikat pekerja) dengan manajemen perusahaan. Serikat pekerja (union) adalah sebuah organisasi yang berunding bagi para karyawan tentang upahupah, jam-jam kerja, dan syarat-syarat dan kondisi pekerjaan lainnya (Henry Simamora, 1997). Sedangkan Undang-Undang Republik Indonesia No. 21 tentang Serikat Pekerja Pasal 1 mendefinisikan serikat pekerja sebagai, organisasi pekerja yang bersifat mandiri, demokratis, bebas, dan bertanggung jawab yang dibentuk dari, oleh, dan untuk pekerja guna memperjuangkan hak dan kepentingan kaum pekerja, dan keluarganya. Sifat-sifat serikat pekerja itu mengandung arti sebagai berikut: (1) Mandiri, yakni keberadaannya tidak dikendalikan oleh pihak manapun melainkan oleh kekuatan sendiri baik dalam mendirikan, menjalankan, maupun mengembangkan organisasi; (2) Demokratis, yakni dalam pembentukan organisasi, pemilihan pengurus, memperjuangkan dan melaksanakan hak-hak dan kewajibannya dilakukan sesuai dengan prinsip-prinsip demokrasi, yaitu mengakui dan menghargai adanya perbedaan pendapat, tidak memaksakan kehendak, serta konsisten melaksanakan putusan yang telah 
ditetapkan bersama; (3) Bebas, yakni sebagai organisasi di dalam melaksanakan hak-hak dan kewajibannya tidak dibawah pengaruh atau tekanan pihak lain; (4) Bertanggung jawab, yakni dalam mencapai tujuan dan melaksanakan hak dan kewajiban bertanggung jawab kepada anggota, masyarakat, dan negara.

Serikat pekerja dipandang sebagai organisasi yang memberikan kegunaan bagi pekerja dan bersifat normatif (Schein, 1980, dalam Kelloway dan Julian Barling, 1993, hal: 262). Sebagai organisasi yang memberikan kegunaan, serikat pekerja menyediakan kepada anggotanya beberapa manfaat melalui proses tawar menawar bersama (Freeman dan Medoff, 1984 dalam Kelloway dan Julian Barling, 1993, hal: 262). Sebagai organisasi normatif keberadaan serikat pekerja ditandai dengan kurang berperannya pekerja di dalam organisasi, dalam hal ini keterlibatan moral di dalam serikat pekerja (Schein, 1980, dalam Kelloway dan Julian Barling, 1993, hal: 262). Kegunaan dan sifat normatif dari serikat pekerja merupakan sumber dari perbedaan dalam partispasi pekerja di dalam serikat pekerja. Menurut Olson 1970 (dalam Kelloway dan Julian Barling, 1993, hal: 262) lebih 90 persen anggota serikat pekerja tidak menghadiri pertemuan organisasi, di lain sisi lebih dari 90 persen anggota serikat pekerja memberikan suaranya sebagai kekuatan untuk memiliki serikat pekerja dan sedapat mungkin membayar iuran organisasi. Menurut Nicholson, 1978 (dalam Kelloway dan Julian Barling, 1993, hal :262), hanya sedikit perhatian terhadap definisi partisipasi pekerja di dalam serikat pekerja. Partisipasi pekerja di dalam serikat pekerja merupakan bentuk perilaku yang terus menerus dioperasionalkan dengan sedikit usaha untuk memahami bagaimana bentuk partisipasi tersebut dapat dapat dihubungkan. Menghadiri pertemuan, membayar iuran, menggunakan prosedur keluhan merupakan indikator dari partisipasi pekerja di dalam serikat pekerja.

Partisipasi pekerja di dalam serikat pekerja menjadi penting karena hal ini merupakan indikasi dukungan pekerja terhadap serikat pekerja (Anderson, 1978, dalam Aryee dan Deebrah, 1997, hal: 130). Penelitian mengenai partisipasi pekerja diadopsi berdasarkan serikat pekerja sebagai organisasi dan konsisten dengan definisi bahwa organsiasi sebagai institusi bersama dengan mempertunjukkan keadaan yang permanen (Child Loveridge dan Warner, 1973 dalam Aryee dan Deebrah, hal: 130). Kondisi permanen tersebut dijelaskan dari keterlibatan pekerja secara spesifik dalam peran dan perilaku di organisasi.

Serikat pekerja muncul akibat adanya industrialisasi. Pada masa praindustrialisasi kebanyakan pekerja adalah pekerja mandiri yang bekerja di rumah dan tanahnya sendiri. Industrialisasi telah menyebabkan melemahnya sistem kemandirian ini dan mengakibatkan banyak pekerja tergantung pada pemilik bengkel, pabrik, atau perusahaan untuk mendapatkan pekerjaan dan penghasilan. Industrialisasi juga memisahkan fungsi-fungsi manajemen dan tenaga kerja (Simamora, 1997).

Kehadiran serikat pekerja secara signifikan mengubah beberapa aktivitas sumber daya manusia. Proses perekrutan, prosedur seleksi, tingkat-tingkat upah, kenaikan gaji, paket tunjangan, sistem keluhan, dan prosedur disiplin dapat berubah secara drastis disebabkan oleh persyaratan perjanjian perburuhan (labor agreement). Tanpa serikat pekerja perusahaan-perusahaan leluasa membuat keputusan-keputusan unilateral (unilateral decisions) menyangkut gaji, jam kerja, kondisi-kondisi kerja. Keputusan-keputusan ini dapat dilakukan oleh perusahaan tanpa masukan-masukan atau persetujuan dan karyawan. Karyawan-karyawan yang tidak berpartisipasi di dalam serikat pekerja mestilah menerima persyaratan manajemen, menegosiasikannya sendiri jika ingin mengubahnya, atau keluar dari perusahaan. Bagaimanapun pada saat karyawan berpartisipasi di dalam serikat pekerja sehingga memiliki wakil serikat pekerja, perusahaan diwajibkan mengasosiasikan dengan serikat pekerja dalam pengambilan keputusan bilateral (bilateral decision making), mengenai tingkat gaji, jam kerja, kondisi kerja, dan masalah-masalah lain dari keamanan pekerjaan. Untuk menghadapi setiap karyawan secara satu persatu perusahan mestilah berunding dengan serikat pekerja yang mewakili pekerja.

Dengan semakin besarnya partisipasi pe- 
kerja di dalam serikat pekerja akan memperbesar pengaruh mereka ke dalam wilayah-wilayah lain manajemen seperti penjadwalan kerja, penyusunan standar kerja, desain ulang pekerjaan, dan pengenalan peralatan dan metode baru. Perusahaan-perusahaan biasanya menolak pelanggaran batas ke dalam wilayah-wilayah pengambilan keputusan ini dengan mengakui secara sepihak bahwa persoalan-persoalan ini merupakan hak prerogratif manajemen. Apakah manajemen berhasil dalam mempertahankan pengendalian eksklusif terhadap hak-hak prerogratif ini akan tergantung pada kekuatan relatif dan kedua belah pihak dalam perundingan kolektif (collective bargaining) dan pada resolusi terhadap konflik-konflik lainnya seperti keluhan, pemogokan, dan perlambatan kerja.

Kebanyakan pekerja menginginkan upah yang tinggi dan kondisi kerja yang baik, artinya pekerja dapat melaksanakan pekerjaanya terlindung dari kemungkinan kecelakaan maupun kondisi kerja yang baik meliputi antara lain hubungan kerja yang harmonis antarpekerja maupun antara pekerja dengan manajemen. Untuk dapat mencapai hasil seperti yang diinginkan pekerja sering tidak memiliki kemampuan tawar menawar dengan pihak manajemen untuk menuntut upah yang tinggi serta kondisi kerja yang baik. Untuk meningkatkan kemampuan tawar menawar dengan pihak manajemen, alternatif yang sangat rasional bagi pekerja adalah dengan membentuk serikat pekerja dan berpartisipasi di dalamnya.

Keberadaan serikat pekerja meskipun secara hukum merupakan hal yang legal bagi setiap pekerja, namun sering kurang mendapatkan tanggapan positif dari pihak manajemen. Hal ini disebabkan karena pihak manajemen tidak ingin ada campur tangan pihak lain yang memaksakan kehendak sehingga tidak sesuai dengan garis kebijaksanaan manajemen.

Dengan semakin banyaknya serikat pekerja yang muncul terutama setelah era reformasi sekarang ini, membuktikan bahwa serikat pekerja yang dulu hanya diwakili oleh SPSI ternyata tidak memberikan harapan yang baik bagi pekerja. Sekarang ini pekerja mempunyai banyak pilihan untuk berpartisipasi di dalam serikat pekerja, dan munculnya serikat pekerja bagai ingin membuktikan bahwa kesadaran pekerja akan hak-hak mereka semakin tinggi.

Ketidakpuasan terhadap Manajemen. Ketika seseorang menerima pekerjaan, kondisikondisi tertentu pekerjaan(upah, jam kerja, dan jenis pekerjaan) disebutkan dalam kontrak pekerjaan. Suatu kontrak psikologis juga terdapat antara perusahaan dengan pekerja berisikan harapan-harapan tidak tertulis pekerja mengenai kondisi-kondisi kerja yang memadai, kebutuhan-kebutuhan untuk pekerjaan tersebut, serta wujud otoritas yang dimiliki perusahaan dalam mengarahkan pekerjaan pada pekerja. Harapan-harapan ini berkaitan dengan keinginan pekerja untuk memuaskan preferensi-preferensi pribadinya di tempat kerja. Seberapa jauh perusahaan mampu memuaskan preferensipreferensi ini untuk menentukan tingkat kepuasaan pekerja. Pekerja menginginkan kompensasi mereka agar wajar dan adil. Upah penting bagi mereka karena upah menyediakan kebutuhan hidup dan kesenangan-kesenangan. Jika pekerja tidak puas dengan upahnya, maka mereka kemungkinan akan berpartisipasi di dalam serikat pekerja untuk meningkatkan standar hidup mereka (Simamora, 1997).

Beberapa istilah dan pengertian banyak digunakan dalam pembahasan upah. Pertama, ada perbedaan antara upah uang (money wages), upah riil (real wages), dan biaya tenaga kerja (labour costs). Upah uang adalah pembayaran secara tunai yang diterima pekerja untuk pekerjaannya. Pekerja tidak hanya berkepentingan pada pembayaran dalam uang, tetapi pada barang dan jasa yang dapat dibeli dengan upahnya. Inilah yang disebut dengan upah riil. Jika upah uang naik, tetapi harga pangan, sandang, perumahan dan kebutuhan lainnya naik lebih tinggi, upah riil turun dan pekerja serta keluarganya menjadi lebih miskin. Di banyak negara, terutama di negara berkembang, upah dibayarkan sebagian dalam uang dan sebagian dalam jenis, seperti beras, transport, pengobatan dan kebutuhan lain. Nilai total upah dalam uang dapat dihitung dengan memperkirakan nilai pasar dari pembayaran dalam jenis, dan menambahkannya dalam pembayaran uang. Nilai total dalam uang dari upah yang dibayarkan 
pengusaha, bersama dengan pembayaran lain untuk pekerjanya (jaminan sosial, pendidikan/ pelatihan) merupakan biaya tenaga kerja, dan menjadi bagian dari total biaya produksinya (Sentanoe, 1995).

Pembedaan upah lainnya adalah antara upah paruh waktu (time rates) dan upah potong (piece rates) atau metode pembayaran lainnya dimana upah dihubungkan dengan hasil produksi (output) sehingga pekerja memiliki insentif untuk menaikkan produksinya. Dalam upah waktu pekerja dibayar dalam upah tertentu karena bekerja satu jam, hari, minggu, atau bulan. Dalam upah potong, pekerja menerima upah karena mengerjakan suatu kuantitas pekerjaan tertentu. Misalnya: memasang 500 bata. Pekerja yang cepat dan bersemangat akan melakukan lebih banyak pekerjaan dan memperoleh lebih banyak upah dan pekerja yang lambat dan malas (Sentanoe, 1995).

Oleh karena itu, upah masuk ke dalam kebijakan dan hubungan antara pekerja, pengusaha, dan pemerintah. Semua pihak itu mempunyai kepentingan untuk meningkatkan kuantitas barang dan jasa, yang memberikan upah, laba, dan penghasilan. Namun kontroversi sering timbul mengenai bagaiman kue barang dan jasa ini harus dibagi diantara mereka. Dimana serikat pekerja telah mantap, kekuatan tawar menawar atas upah dengan pengusaha sering sangat tajam. Meskipun masing-masing pihak menginginkan mencapai kesepakatan, perbedaan antara upah yang ditawarkan oleh pengusaha dan jumlah yang mau diterima pekerja bisa terlalu besar untuk tercapinya suatu penyelesaian. Dalam keadaan itu, konflik tajam terjadi dan kekuatan masing-masing pihak akhirnya ditunjukkan dengan mogok atau penutupan perusahaan sampai satu pihak terpaksa mengalah atau tercapai kompromi.

Selain upah hal lain yang sering dipermasalalikan oleh pekerja atau karyawan adalah masalah kondisi kerja. Pada pembicaraan sehari-hari kondisi kerja sering disalahtafsirkan dengan lingkungan kerja, padahal sebenamya kondisi kerja merapakan salah satu faktor dari lingkungan kerja. Kondisi kerja adalah kondisi yang dapat dipersiapkan oleh manajemen perusahaan yang bersangkutan pada waktu per- usahaan akan didirikan oleh perusahaan tersebut (Agus Asyhari, 1994, dalam Indra Gunawan, 2000, hal: 18). Kondisi kerja sangat berkaitan dengan layout pabrik, oleh sebab itu kondisi kerja harus direncanakan bersamaan pada saat perencanaan pembangunan pabrik. Tujuan untuk merencanakan kondisi kerja dalam perusahaan sesuai dengan tujuan dari perencanaan kerja adalah untuk meningkatkan produktivitas kerja karyawan (Agus Asyhari, 1994, dalam Indra Gunawan, 2000, hal: 19).

Menurut Robbins (1993, dalam Djoddy Ismanto 2000, hal :20), karyawan akan memperhatikan kondisi kerjanya demi kenyamanan pribadi dan agar dapat melakukan pekerjaan dengan baik. Karyawan lebih suka dalam kondisi kerja yang tidak berbahaya dan nyaman. Suhu, cahaya, tingkat kebisingan, dan sebagainya tidak ekstrem. Selain itu kebanyakan karyawan lebih suka apabila tempat kerjanya relatif dekat dengan rumah, dalam lingkungan yang bersih, fasilitas yang modern dan dilengkapi dengan peralatan dan mesin yang memadai.

Faktor-faktor kondisi kerja yang harus direncanakan selaras dengan perencanaan pabrik adalah: (1) Penerangan. Penerangan di dalam kondisi kerja ini adalah cukupnya sinar matahari yang masuk di dalam ruang kerja masing-masing karyawan perusahaan; (2) Suhu Udara. Suhu udara pada ruang kerja para karyawan perusahaan akan ikut mempengaruhi produktivitas kerja para karyawan perusahaan yang bersangkutan; (3) Suara Bising. Suara bising yang terjadi di dalam ruang produksi pada umumnya belum mendapat perhatian dengan semestinya; (4) Ruang gerak yang diperlukan agar para karyawan perusahaan yang bersangkutan ini dapat leluasa bergerak dengan baik, maka ruang untuk karyawan ini haruslah memadai.

Selain upah dan kondisi kerja, masalah lain yang sering muncul antara manajemen dengan pekerja adalah masalah keamanan kerja, dimana yang biasanya terjadi adalah masalah pemecatan terhadap karyawan dan munculnya praktek pensubkontrakkan kerja. Masalah-masalah ini masing sering terjadi, sehingga pekerja berusaha untuk memasukkan klausa-klausa ter- 
sebut ke dalam kesepakatan kerja bersama.

Bila pekerja merasa tidak puas dengan aspek-aspek lingkungan kerjanya, seperti upah, kesempatan promosi, perlakuan oleh atasan, pekerjaan itu sendiri, dan peraturan-peraturan kerja mereka mungkin berpendapat bahwa dengan berpartisipasi di dalam serikat pekerja akan dapat membantu memperbaiki situasi. Jika mereka percaya bahwa serikat pekerja mampu membantu, mereka kemudian akan menimbang manfaat dan kerugian bila mereka berpartisipasi di dalam serikat pekerja. Semakin percaya serikat pekerja dapat menghasilkan pekerjaan yang positif, pekerja akan beranggapan dengan berpartisipasi aktif di dalam serikat pekerja akan semakin instrumental dalam menghapuskan penyebab ketidakpuasan (Maryono dan Sri Sudarsi, 2000). Menurut Freeman dan Medoff, 1984 (dalam Yitchak Haberfeld, 1995, hal: 657), "...serikat pekerja menyediakan pekerja suara bersama dalam rangka menghilangkan sumber ketidakpuasan".

Ketidakpuasan terhadap persyaratan-persyaratan dan kondisi-kondisi implisit pekerjaan akan membuat pekerja berupaya mengubah situasi pekerjaan, seringkali melalui serikat pekerja. Suatu studi penting menemukan hubungan yang sangat kuat antara tingkat kepuasan dan proporsi para pekerja untuk berpartisipasi di dalam serikat pekerja (Maryono dan Sri Sudarsi, 2000). Partisipasi pekerja di dalam serikat pekerja disebabkan karena mereka mempunyai masalah dalam kerja, kemudian upah dan kondisi kerja (Waddington dan Whitson, 1997 dalam Paul Tolich dan Mark Harcourt, 1996, hal: 66). Menurut George R. Grai dan Myers (1999, hal:38), mengatakan bahwa usaha untuk melindungi dan mendorong pekerja dan untuk memastikan perlakuan adil terhadap pekerja merupakan dasar yang kuat bagi kepercayaan antara manajemen dan pekerja. Demikian pula dengan penelitian yang dilakukan oleh Paul Tolich dan Mark Harcourt (1996), yang mengatakan bahwa masalah di dalam kerja merupakan salah satu faktor yang mempengaruhi partisipasi pekerja di dalam serikat pekerja. Penelitian lain mengatakan bahwa, negoisasi mengenai upah dan kondisi kerja merupakan salah satu faktor kunci yang mempengaruhi pekerja untuk berpartisipasi di dalam serikat pekerja (Kerr, 1992, dalam Paul Tolich dan Mark Harcourt, 1995, hal:66). Menurut Freeman dan Medoff, 1984 (dalam Yitchak Heberteld, 1995, hal:657) menyatakan bahwa ketidakpuasan kerja dan rasa frustasi merupakan alasan pekerja untuk berpartisipasi di dalam serikat pekerja.

Kegunaan atau Manfaat Serikat Pekerja. Secara umum serikat pekerja bertujuan untuk mempromosikan kepentingan para anggota dan kelangsungan hidup dari serikat pekerja itu sendiri serta berusaha mempertahankan atau meningkatkan dukungan pekerja dengan menyediakan kebutuhan-kebutuhan mereka (Maryono dan Sri Sudarsi, 2000). Sedangkan FSPSI mendefinisikan fungsinya sebagai berikut (1) Pembela dan pelindung hak-hak dan kepentingan serta penyalur aspirasi pekerja; (2) Pendorong dan penggerak pekerja dalam turut menyukseskan program-program pembangunan nasional, khususnya pembangunan sosial ekonomi; (3) Wahana peningkatan kesejahteraan pekerja; (4) Wadah pembinaan kader-kader bangsa yang menunjang pembangunan secara profesional, disiplin, trampil, produktif, dan berwawasan kebangsaan; (5) Mitra yang aktif dalam proses pengambilan keputusan politik ketenagakerjaan serta pelaksanaan kontrol sosial terhadap pelaksanaannya.

Beberapa studi mengemukakan bahwa pekerja memandang manfaat atau kegunaan serikat pekerja dari dua aspek yaitu, manfaat bersama dan manfaat individu. Menurut Waddington dan Whitson, 1997 (dalam Paul Tolich dan Mark Harcourt, 1996, hal:65), manfaat bersama adalah hal-hal yang berkaitan dengan organisasi secara keseluruhan dan memasukkan dukungan yang saling menguntungkan serta perbaikan upah dan kondisi kerja. Sedangkan manfaat individu adalah pelatihan dan pendidikan, pelayanan hukum, dan keuangan. Lebih lanjut Waddington menyatakan bahwa manfaat bersama untuk berpartisipasi di dalam serikat pekerja tetap lebih penting dibandingkan manfaat individu. Menurut Phelps Brown, 1990 (dalam Paul Tolich dan Mark Harcourt, 1996, hal:66) beberapa peneliti mengungkapkan bahwa partisipasi pekerja di dalam serikat pekerja lebih banyak disebabkan oleh manfaat individu dibandingkan manfaat bersama. Menurut Paul 
Tolich dan Mark Harcourt (1996, hal:65), penelitian sekarang mengasumsikan bahwa pekerja berpartisipasi dalam serikat pekerja lebih banyak disebabkan oleh kebutuhan akan manfaat bersama dibandingkan manfaat individu.

Menurut survei yang dilakukan oleh Peetz (1997, dalam Paul Tolich dan Mark Harcourt, 1996, hal:66) yang melakukan studi terhadap 942 tenaga kerja dari 35 tempat kerja menemukan bahwa, hampir setengah dari responden menjelaskan alasan mereka berpartisipasi di dalam serikat pekerja dikarenakan alasan perlindungan, nasehat, dan adanya perwakilan buat mereka. Menurut penelitian terhadap 3000 tenaga kerja di Victoria Australia yang dilakukan oleh Creegan, Johnston, dan Bartram, 1994 (dalam Paul Tolich dan Mark Harcourt, 1996, hal:66), menemukan bahwa 94 persen anggota berpartisipasi di dalam serikat pekerja karena alasan perlindungan kerja dan hak-hak pekerja, kemudian 25 persen karena dukungan moral, 26 persen karena kondisi kerja, dan 21 persen karena alasan solidaritas. Menurut Anat Levy (1990, hal:41), pekerja mempunyai hasrat untuk berpartisipasi di dalam serikat pekerja apabila serikat pekerja memberikan kegunaan bagi pekerja

Politik atau Kepercayaan Ideologi. Negara-negara di dunia ketiga sangat turut campur dan berusaha untuk mengontrol setiap aspek dari sistem hubungan industrial. Keterlibatan pemerintah dalam sistem hubungan industrial di berbagai negara dunia ketiga hampir secara total dan secara kualitatif berbeda dengan yang ada di barat (Shaheed,1997 dalam S.A. Siddique, hal:394). Dengan ikut campurnya pemerintah dalam hubungan industrial, secara langsung atau pun tidak langsung pemerintah mencoba mempertahankan kepentingannya terutama dalam bidang ekonomi dan politik perburuhan. Hal ini dapat dilihat dari kebijakan buruh murah, yang akhirnya menimbulkan sentimen-sentimen terhadap sistem ekonomi kapitalis.

Kebanyakan rumah tangga di negara berkembang lebih mencurahkan pekerjaannya untuk memproduksi secara langsung bagi pemenuhan kebutuhan mereka sendiri terutama kebutuhan makanan (Freund, 1981; 5, dalam S.A.
Siddique, hal: 391). Hal tersebut merupakan pola dalam pembentukan kelas dalam konteks kelas pekerja di negara berkembang yang telah memperlemah posisi kelas pekerja dengan dua cara, pertama diciptakan sebuah pembagian kelas pekerja yang dapat disebut sebagai "semi proletariat", dan kedua mencegah perkembangan pasar tenaga kerja di negara-negara berkembang. Lebih jauh, keberadaan berbagai kelompok di dalam kelas pekerja telah memunculkan konflik ideologis dan kepentingan di antara mereka di negara berkembang (Taylor 1979; 238, dalam S.A. Siddique, hal:391). Posisi lemah yang dimiliki kelas pekerja di negara berkembang telah mendesak mereka untuk terpaksa melakukan tindakan politik untuk mengatasi kekurangan mereka. Para pekerja di negara berkembang mendapati bahwa tindakan politik lebih efektif daripada tindakan ekonomi untuk menyelesaikan permasalahan mereka (Clegg, 1976; 4, dalam S.A.Siddique, hal:391). Menurut Deery dan De Cieri, 1991 (dalam Paul Tolich dan Mark Harcourt, 1996, hal:70), kepercayaan ideologi merupakan motif kunci bagi pekerja untuk berpartisipasi di dalam serikat pekerja. Demikian pula dengan penelitian yang dilakukan oleh Paul Tolich dan Mark Harcourt (1996, hal: 71) dimana mereka menemukan bahwa, kepercayaan terhadap politik serikat pekerja merupakan alasan kedua terpenting untuk berpartisipasi di dalam serikat pekerja. Menurut Yitchak Haberfeld (1995, hal:658), pekerja berpartisipasi di dalam serikat pekerja merupakan hasil dari kepercayaan politik, di beberapa negara serikat pekerja berafiliasi dengan partai politik.

Penelitian Terdahulu. Hasil penelitian terdahulu tentang alasan pekerja untuk masuk serikat pekerja terangkum dalam Tabel 1 .

Hipotesis. H1 adalah Ketidakpuasan terhadap manajemen berpengaruh positif terhadap partisipasi pekerja di dalam serikat pekerja; H2 adalah Manfaat bersama berpengaruh positif terhadap partisipasi pekerja di dalam serikat pekerja; H3 adalah Manfaat individu berpengaruh positif terhadap partisipasi pekerja di dalam serikat pekerja; H4 adalah Kepercayaan politik atau ideologi berpengaruh positif terhadap partisipasi pekerja di dalam serikat pekerja; 
Tabel 1. Penelitian Terdahulu

\begin{tabular}{|c|c|c|}
\hline Judul & Pengarang & Hasil Penelitian \\
\hline $\begin{array}{l}\text { Why do people join unions? a case } \\
\text { study of the New Zealand engineer- } \\
\text { ing, printing and manufacturing } \\
\text { union (1999) }\end{array}$ & $\begin{array}{l}\text { Paul Tolich dan } \\
\text { Mark Harcourt }\end{array}$ & $\begin{array}{l}\text { Kebanyakan pekerja berpartisipasi dengan } \\
\text { serikat pekerja karena mereka mempunyai } \\
\text { masalah dengan kerja dan disebabkan mereka } \\
\text { percaya terhadap serikat pekerja }\end{array}$ \\
\hline $\begin{array}{l}\text { Why do workers join unions? The } \\
\text { case of Israel (1995) }\end{array}$ & Yitchak Haberfeld & $\begin{array}{l}\text { Pekerja di Israel berpartisipasi dengan serikat } \\
\text { pekerja karena non work benefit dan social } \\
\text { value }\end{array}$ \\
\hline $\begin{array}{l}\text { Heterogeneity and union membership } \\
\text { determination (1990) }\end{array}$ & Anat Levy & $\begin{array}{l}\text { Ada dua kondisi yang haras diperoleh pekerja } \\
\text { untuk berpartisipasi dengan serikat pekerja } \\
\text { yang pertama adalah dengan berpartisipasi } \\
\text { dengan serikat pekerja, pekerja berharap ada } \\
\text { peningkatan upah, kedua dengan } \\
\text { berpartisipasi dengan serikat pekerja, pekerja } \\
\text { akan memperoleh manfaat tambahan. }\end{array}$ \\
\hline $\begin{array}{l}\text { Why while collar staff join trade } \\
\text { union. (1994) }\end{array}$ & $\begin{array}{l}\text { IRS Employment } \\
\text { Trends (news) }\end{array}$ & $\begin{array}{l}\text { Pekerja berpartisipasi dalam serikat pekerja } \\
\text { karena mempunyai masalah dengan } \\
\text { kerjakebanyakan pekerja adalah anggota } \\
\text { serikat pekerja, kepercayaan terhadap serikat } \\
\text { pekerja, ingin memperbaiki upah dan kondisi } \\
\text { kerja, dan pelatihan dan pendidikan. }\end{array}$ \\
\hline $\begin{array}{l}\text { Determinant of Australian trade } \\
\text { unions membership (1998) }\end{array}$ & $\begin{array}{l}\text { C. Cregan, S. } \\
\text { Johnson, T. Bartram }\end{array}$ & $\begin{array}{l}\text { Pekerja berpartisipasi dengan serikat pekerja, } \\
\text { karena ingin melindungi pekerjaan dan hak- } \\
\text { hak mereka, dukungan moral, negosiasi upah } \\
\text { dan kondisi kerja, serta solidaritas }\end{array}$ \\
\hline $\begin{array}{l}\text { Why join? WJiy stay? union, } \\
\text { employer and aspect of union } \\
\text { membershipm Australia (1997) }\end{array}$ & D.Peetz & $\begin{array}{l}\text { Lebih dan setengah responden berpartisipasi } \\
\text { dengan serikat pekerja karena alasan } \\
\text { perlindungan, nasehat dan mempunyai wakil. }\end{array}$ \\
\hline $\begin{array}{l}\text { Why do people join unions in a } \\
\text { period of membership decline } \\
(1997)\end{array}$ & $\begin{array}{l}\text { Waddington, } \\
\text { Jeremy, Whitston, } \\
\text { and Colin }\end{array}$ & $\begin{array}{l}\text { Pekerja berpartisipasi dengan serikat pekerja } \\
\text { disebabkan karena manfaat bersama }\end{array}$ \\
\hline
\end{tabular}

Sumber: berbagai sumber

H5 adalah ketidakpuasan terhadap manajemen, manfaat bersama, manfaat individu dan kepercayaan politik atau ideologi secara bersamasama berpengaruh terhadap partisipasi pekerja di dalam serikat pekerja

\section{METODE PENELITIAN}

\section{Jenis Penelitian}

Jenis penelitian yang digunakan dalam penelitian ini adalah penelitian explanatory yaitu jenis penelitian yang menjelaskan hubungan se- bab akibat antara variabel-variabel melalui pengujian hipotesis (Masri Singarimbun, 1989). Sedangkan metode yang digunakan adalah metode survei

\section{Populasi dan Sampel}

Populasi yang akan diteliti dalam penelitian ini adalah pekerja yang menjadi anggota serikat pekerja pada perusahaan-perusahaan di Kota Semarang yang terdaftar di Departemen Tenaga Kerja Kota Semarang. Yang dimaksud dengan pekerja di sini adalah tenaga kerja yang 
bekerja di dalam hubungan kerja pada pengusaha dengan menerima upah. Sampel diambil dengan metode cluster random sampling. Teknik ini digunakan karena obyek yang akan di teliti sangat luas, sehingga pengambilan sampel dilakukan melalui beberapa tahap. Tahap pertama, adalah dengan membagi jumlah serikat pekerja berdasarkan sektor usaha, dimana terdapat 10 sektor usaha. Kemudian dari masingmasing sektor usaha dipilih secara acak untuk memperoleh satu serikat pekerja di perusahaan untuk masing-masing sektor usaha, sehingga akhirnya diperoleh 10 serikat pekerja yang mewakili tiap-tiap sektor usaha. Dari masingmasing serikat pekerja diambil sampel secara acak proporsional sebanyak 30 orang, sehingga jumlah sampel keseluruhan sebanyak 300 responden (30 x 10 perusahaan).

\section{Jenis dan Sumber Data}

Data primer diperoleh melalui kuesioner yang disebarkan, dimana kuesioner tersebut berisi pertanyaan-pertanyaan yang berkaitan dengan opini responden mengenai variabel-variabel penelitian, yaitu partisipasi pekerja di dalam serikat pekerja, ketidakpuasan terhadap manajemen, manfaat bersama, manfaat individu, dan kepercayaan politik atau ideologi. Data sekunder diperoleh dari lembaga-lembaga lain dimana data-data tersebut berkaitan dan mendukung terhadap permasalahan yang diteliti.

\section{Definisi Operasional Variabel}

Partisipasi di dalam serikat pekerja adalah persepsi anggota serikat pekerja terhadap kewajiban-kewajibannya sebagai anggota serikat pekerja dilihat dan mematuhi AD/ART, membela serikat pekerja, membayar iuran, aktif menghadiri pertemuan, diukur dengan menggunakan skala likert 1-5.

Ketidakpuasan terhadap manajemen adalah persepsi pekerja terhadap kondisi-kondisi normatif kerja yang mereka hadapi, dilihat dari upah, kondisi kerja, dan keamanan kerja, diukur dengan menggunakan skala likert 1-5 (Yitehak Haberfeld, 1995; hal: 664).

Manfaat bersama adalah persepsi pekerja terhadap keuntungan-keuntungan bersama yang diharapkan yang akan diperoleh dengan berpartisipasi di dalam serikat pekerja dilihat dari diikungan moral, solidaritas, dan diukur dengan menggunakan skala likert 1-5 (Yitchak Haberfeld, 1995; hal: 658).

Manfaat individu adalah persepsi pekerja terhadap keuntungan-keuntungan pribadi yang diharapkan akan diperoleh dengan berpartisipasi di dalam serikat pekerja dilihat dari perwakilan, perlindungan, pendidikan dan pelatihan, dan diukur dengan skala likert 1-5 (Yitchak Haberfeld, 1995; hal:658).

Kepercayaan politik atau ideologi adalah persepsi pekerja terhadap ideologi ataupun kepercayaan politik serikat pekerja, dilihat dari kepercayaan terhadap serikat pekerja sebagai tempat untuk menyalurkan aspirasi politik dan hubungan serikat pekerja dengan partai politik, diukur dengan skala likert 1-5 (Paul Tolich dan Mark Harcourt, 1995; hal:71, Yitchak Haberfeld, 1995; hal:658).

Skala pengukuran yang digunakan adalah skala pengukuran ordinal, skala ini digunakan untuk mengukur persepsi responden terhadap suatu jawaban. Dalam menentukan bobot (skor) digunakan skala likert yang terbagi ke dalam 5 jenjang yaitu: (a) Katagori jawaban sangat tinggi diberi skor 5; (b) Kategori jawaban tinggi diberi skor 4; (c). Kategori jawaban sedang diberi skor 3; (d). Kategori jawaban sedang rendah diberi skor 1 .

\section{Uji Instrumen Penelitian}

Kuesioner yang dipakai harus diuji validitas dan reliabilitasnya terlebih dahulu. Uji validitas dimaksudkan untuk mengukur sejauh mana ketepatan dan kecermatan suatu alat ukur dalam melakukan fungsi memberikan hasil ukur yang sesuai. Pengukuran dilakuikan dengan teknik korelasi skor item dan skor total product moment correlation. Indikator dinyatakan valid apabila menunjukkan nilai $\mathrm{r}$ product moment correlation lebih besar dari 0,40 .

Uji reliabilitas dimaksudkan untuk mengukur sejauh mana suatu pengukuran dapat dipercaya atau dapat diandalkan atau seberapa konsisten suatu instrumen mengukur konsepkonsep yang ada. Pengukuran dilakukan terhadap estimasi keseluruhan test dengan menggunakan koefisien alpha yang dikemukakan oleh 
Cronbach. Keterandalan suatu indikator dapat dilihat dari nilai Alpha Cronbach lebih besar dari 0,60 (Dongoran,1987).

\section{Teknik Analisis Data}

Untuk menguji faktor-faktor yang mempengaruhi partisipasi pekerja di dalam serikat pekerja adalah dengan model regresi linier berganda. Analisa regresi merupakan analisis yang digunakan untuk melihat hubungan yang ada di antara variabel-variabel sehingga dari hubungan yang diperoleh kita dapat menaksir variabel yang satu apabila harga variabel lainnya diketahui (Sudjana, 1997). Sedangkan analisa regresi bertujuan untuk memperkirakan nilai dari variabel-variabel tak bebas pada nilai variabel bebas tertentu (J. Supranto,1987). Dalam penelitian ini persamaan regresi yang dibuat adalah sebagai berikut:

$\mathrm{Y}=$ bo + bi $x 1+b 2 \times 2+b 3 \times 3+b 4 \times 4+e$

dimana: $\mathrm{Y}$ adalah partisipasi pekerja di dalam serikat pekerja; bo adalah intersep; b1-b4 adalah koefisien regresi parsial untuk variabel $\mathrm{xl}-\mathrm{x} 4$; $\mathrm{x}$ adalah ketidakpuasan terhadap manajemen; $x 2$ adalah manfaat bersama; $x 3$ adalah manfaat individu; $x 4$ adalah kepercayaan politik atau ideologi; el adalah galat (kesalahan penggang$\mathrm{gu})$.

Berdasarkan pada hasil analisis linier berganda tersebut akan dapat diketahui pengaruh dan tingkat signifikansi masing-masing variabel bebas terhadap keputusan masuk ke dalam serikat pekerja. Selanjutnya besarnya kontribusi secara simultan (koefisien determinasi) diperoleh dengan rumus:

$$
R^{2}=\frac{\text { SSregresi }}{\text { SSTotal }}
$$

Kalau diuraikan menjadi sebagai berikut:

$$
R^{2}=\frac{\text { SSregresi }- \text { SSresidu }}{\text { SStotal }}=1-\frac{\text { SSresidu }}{\text { SStotal }}=1-\frac{e}{Y}
$$

Dari hasil regresi yang diperoleh, kemudian dilakukan pengujian untuk mengetahui apakah koefisien regresi yang diperoleh mem- punyai pengaruh yang signifikan atau tidak, baik secara simultan maupun parsial, dan untuk mengetahui pula seberapa besar pengaruhnya. Dalam hal ini ada dua bentuk pengujian, yaitu: (1) Uji t statistik untuk menguji pengaruh antara variabel bebas terhadap variabel tak bebas secara parsial dengan mengasumsikan bahwa variabel lain dianggap konstan dengan tingkat kepercayaan $95 \%$, df $=n-k$, nilai $t$ tabel dibandingkan dengan nilai t hitung yang diperoleh untuk menentukan apakah pengaruhnya signifikan atau tidak. Bila $t$ hitung $>t$ label, maka Ho ditolak atau menerima Ha, sebaliknya bila $t$ hitung $<\mathrm{t}$ tabel, maka Ho dinyatakan diterima atau menolak Ha.; (2). Uji F statistik untuk mengetahui pengaruh variabel bebas secara simultan terhadap variabel tergantung $(\mathrm{Y})$, pada tingkat kepercayaan $95 \%$ atau a $=0,05$ dan degree of freedom (derajat kebebasan) df $=\mathrm{n}-\mathrm{k}-1$ akan diperoleh nilai $\mathrm{F}$ tabel, kemudian nilai $\mathrm{F}$ hitung dibandingkan dengan $\mathrm{F}$ tabel untuk menentukan apakah pengaruh simultan signifikan atau tidak. Bila F hitung > F tabel, maka Ho ditolak atau menerima $\mathrm{Ha}$, sebaliknya bila $\mathrm{F}$ hitung $<\mathrm{F}$ tabel, maka Ho dinyatakan diterima atau menolak Ha.

Untuk memperoleh model persamaan linier yang memiliki penduga terbaik (best linier unbiased estimator), dilakukan pengujian atas asumsi klasik regresi, meliputi: (1) Uji normalitas, model regresi yang baik adalah model regresi yang mempunyai distribusi data normal atau mendekati normal dengan melihat normal probability plot dan uji Kolmogorov - Smirnov Test; (2) Multikolinieritas, dengan menentukan variance inflation factor (Santoso, 2000), antar variabel independen haruslah rendah $(<0,70)$; (3) Heteroskedastis, dalam suatu model regresi tidak boleh terjadi ketidaksamaan varians dari residual dari satu pengamatan ke pengamatan lain.

\section{HASIL DAN PEMBAHASAN}

Sebagian besar responden (74,89 persen) mendukung partisipasi pekerja di dalam serikat pekerja bila diukur dari kewajiban-kewajiban yang harus dilakukan oleh anggota serikat pekerja. Mereka (69,50 persen) juga menyata- 
untūk variabel manfaat bersama, mempunyai arti bahwa semakin besar manfaat bersama yang diperoleh pekerja seperti rasa solidaritas dan dukungan moral maka semakin besar partisipasi pekerja di dalam serikat pekerja. Nilai koefisien regresi sebesar 0,457 untuk variabel manfaat individu, memberikan arti bahwa se- men berpengaruh terhadap partisipasi pekerja di dalam serikat pekerja, hal ini sesuai dengan penelitian yang dilakukan oleh Waddington dan Whitson tahun 1997 yang manyatakan bahwa alasan pekerja berpartisipasi dalam serikat pekerja disebabkan karena mereka mempunyai masalah dengan kerja, upah, dan kondisi kerja.

Tabel 2. Nilai t Hitung dan F Hitung untuk Masing-Masing Variabel

\begin{tabular}{|c|c|c|c|c|}
\hline Variabel & t hitung & P value & F hitung & P Value \\
\hline Ketidakpuasan terhadap manajemen & 3,751 & 0,000 & & \\
\hline Manfaat bersama & 5,314 & 0,000 & 60,046 & 0,000 \\
\hline Manfaat individu & 8,557 & 0,000 & & \\
\hline Kepercayaan politik atau ideologi & $-0,320$ & $-0,750$ & & \\
\hline
\end{tabular}

Sumber: Pengolahan Data Primer 
Hal yang sama juga diungkapkan oleh Paul Tolich dan Mark Harcourt (1996) yang menyatakan bahwa masalah di dalam kerja merupakan salah satu faktor yang mempengaruhi pekerja untuk berpartisipasi dalam serikat pekerja. Freeman dan Medoff, 1984 (dalam Yitchak Heberfeld, 1995, hal: 657) juga menyatakan bahwa ketidakpuasan kerja dan rasa frustasi merupakan alasan untuk berpartisipasi di dalam serikat pekerja.

Kondisi ini disebabkan upah yang diterima pekerja masih rendah jika dibandingkan kebutuhan hidup yang harus dijalani oleh pekerja, kemudian kondisi kerja di banyak perusahaan yang masih buruk dan ditambah lagi dengan krisis ekonomi yang terjadi, menyebabkan banyak perusahaan melakukan pemutusan hubungan kerja, sehingga pekerja merasa tidak aman dalam bekerja Dengan kondisi tersebut jelas tidak menguntungkan bagi pekerja, karena pekerja menginginkan kompensasi yang adil dan pada akhimya pekerja merasa perlu untuk berpartisipasi di dalam serikat pekerja untuk dapat memperjuangkan kepentingan mereka.

Variabel manfaat bersama berpengaruh terhadap partisipasi pekerja di dalam serikat pekerja, hal ini sesuai dengan penelitian yang dilakukan oleh Waddington dan Whitson, 1997 yang menyatakan bahwa manfaat bersama lebih penting dibandingkan manfaat individu sebagai alasan untuk berpartisipasi di dalam serikat pekerja. Sedangkan menurut Anat Levy (1990, hal:41), menyatakan bahwa hasrat untuk berpartisipasi dengan serikat pekerja apabila serikat pekerja memberikan kegunaan bagi pekerja.

Manfaat bersama yang diperoleh pekerja dengan berpartisipasi di dalam serikat pekerja yaitu munculnya rasa solidaritas diantara pekerja dan dukungan moral pekerja terhadap pekerja yang lain. Kondisi ini muncul akibat perlakuan-perlakuan yang tidak menyenangkan yang dialami pekerja seperti upah yang rendah. Dengan kondisi ini pekerja akan senang hati untuk menolong temannya yang sedang dilanda kesulitan dan juga mendukung temannya jika temannya tersebut ingin berpartisipasi di dalam serikat pekerja Munculnya rasa solidaritas dan dukungan moral diantara anggota serikat pekerja tentunya akan menguntungkan serikat pekerja, karena dengan sendirinya pekerja akan berpartisipasi aktif di dalam serikat pekerja. Dengan begitu maka serikat pekerja bertambah solid sebagai upaya untuk meningkatkan posisi tawar pekerja dan juga mempermudah melakukan gerakan bersama dalam rangka memperjuangkan hak-hak pekerja dan serikat pekerja

Variabel manfaat individu berpengaruh signifikan terhadap partisipasi pekerja di dalam serikat pekerja Hal ini sesuai dengan penelitian yang dilakukan oleh Peetz, 1995 (dalam Paul Tolich dan Mark Harcourt, 1996, hal: 66), yang menyatakan alasan pekerja untuk berpartisipasi di dalam serikat disebabkan perlindungan hukum, nasehat, dan adanya perwakilan buat mereka

Manfaat individu yang diperoleh pekerja dengan berpartisipasi di dalam serikat pekerja merupakan hal wajar yang diinginkan oleh setiap pekerja. Keinginan untuk memperoleh perlindungan hukum, peningkatan keterampilan, tunjangan pensiun, asuransi kesehatan dan sebagainya merupakan keinginan pekerja yang muncul sebagai akibat dari kurangnya perhatian perusahaan (manajemen) terhadap pekerja. Selain itu salah satu tujuan dari didirikannya serikat pekerja adalah meningkatkan kesejahteraan pekerja (Undang-Undang Republik Indonesia No. 21 Tahun 2000 Tentang Serikat Pekerja pasal 4 ayat 1), dan di era Multi Union ini manfaat-manfaat individu merupakan salah satu cara dari serikat pekerja untuk menarik anggota, sehingga dapat bersaing dengan serikat pekerja lainnya. Dengan adanya manfaat individu ini menyebabkan pekerja merasa perlu untuk berpartisipasi di dalam serikat pekerja.

Variabel kepercayaan politik atau ideologi tidak berpengaruh terhadap keputusan pekerja untuk berpartisipasi di dalam serikat pekerja Hal ini tidak sesuai dengan penelitian terdahulu yang dilakukan oleh Deery dan De Cieri , 1991 (dalam Paul Tolich dan Mark Harcourt, 1995, hal:70) yang menyatakan bahwa kepercayaan ideologi merupakan motif kunci bagi pekerja untuk berpartisipasi di dalam serikat pekerja Demikian pula dengan penelitian yang 
dilakukan oleh Paul Tolich dan Mark Harcourt (1996, hal:71) yang menyatakan bahwa kepercavaan terhadap politik serikat pekeria merupa- maka semakin besar partisipasi pekerja di dalam serikat pekerja. Sedangkan, kepercayaan politik atau ideologi tidak berpengaruh terha-

\section{SIMPULAN}

Dari analisis data dan pembahasan yang telah dilakukan, kesimpulan yang dapat diambil adalah:

(1) Ketidakpuasan terhadap manajemen, manfaat bersama, dan manfaat individu berpengaruh positif terhadap partisipasi pekerja di dalam serikat pekerja. Semakin tidak puas pekerja terhadap manajemen, semakin besar manfaat bersama yang diperoleh pekerja, dan semakin besar manfaat invidu yang diperoleh pekerja, pekerja di dalam serikat pekerja dengan dasar bahwa asas politik atau ideologi yang dianut serikat pekerja adalah Pancasila dan pekerja tidak mengetahui ideologi politik lain selain Pancasila. Selain itu, selama ini pekerja merasa hanya sebagai obyek kepentingan elite politik dimana pemanfaatan massa pekerja untuk kepentingan tertentu lebih menonjol daripada mengurusi nasib pekerja itu sendiri. Sedangkan yang diinginkan oleh pekerja adalah peningkatan kesejahteraan bagi dirinya dan keluarganya.

Implikasi Manajerial 
Sebagian besar pekerja merasa tidak puas dan biasa saja terhadap kondisi-kondisi normatif kerja yang mereka terima di tempat kerja. Hal ini merupakan kenyataan umum yang terjadi pada pada sektor ketenagakerjaan. Pandangan yang menganggap upah pekerja (sebagai salah satu sumber dari ketidakpuasan), sebagai keunggulan kompetitif dalam dunia usaha, sehingga dijadikan sebagai daya tarik investasi, menyebabkan perusahaan (manajemen) akan menganggap pekerja sebagai faktor produksi yang sah untuk ditekan. Selain itu kondisi kerja dan keamanan kerja yang diberikan perusahaan kepada pekerja, sering menjadi sumber ketidakpuasan pekerja. Kondisi ini menyebabkan konflik antara pekerja dan pengusaha selalu muncul dan untuk berhadapan secara personal dengan dengan pengusaha pekerja tentunya akan mengalami kesulitan, sehingga pekerja beranggapan mereka harus berpartisipasi di dalam serikat pekerja untuk mempennudah menyuarakan tuntutannya.

Untuk mengurangi ketidakpuasan pekerja terhadap manajemen, perusahaan (manajemen) dituntut untuk dapat berkomunikasi dengan baik dengan pihak pekerja dan perlu adanya transparansi dari pihak manajemen. Adanya komunikasi yang baik dan adanya transparansi tersebut, maka manajemen dapat mengetahui sejauh mana keterikatan emosional pekerja terhadap manajemen, dan mengetahui masalah-masalah yang menjadi sumber ketidakpuasan. Dalam proses untuk mencapai hal tersebut maka manajemen harus menerapkan manajemen terbuka untuk dapat menciptakan hubungan industrial yang harmonis. Manajemen terbuka di sini tentu saja tidak hanya menyerap aspirasi pekerja yang disuarakan serikat pekerja dengan memenuhi segala hal yang menjadi tuntutan pekerja, tetapi manajemen juga dapat menyampaikan keterbatasan perusahaan secara terbuka sehingga pekerja juga dapat memahami kesulitan-kesulitan yang dihadapi manajemen.

Pekerja merasa solidaritas diantara mereka menjadi semakin tinggi dengan berpartisipasi di dalam serikat pekerja. Kondisi ini tentunya menguntungkan bagi serikat pekerja dan pekerja itu sendiri, dan tentunya juga berpengaruh terhadap manajemen. Manajemen harus lebih berhati-hati dalam mengambil keputusan terutama yang berkaitan dengan pekerja. Menyikapi kondisi tersebut mau tidak mau manajemen harus menganggap serikat pekerja sebagai mitra bukan sebagai musuh dan hubungan yang kooperatif antara manajemen dengan serikat pekerja harus dikembangkan. Hubungan yang kooperatif tersebut dapat tercipta apabila antara serikat pekerja dan manajemen saling berbagi informasi, mencoba memecahkan masalah bersama-sama, dan masingmasing pihak menjalankan fungsinya secara proporsional.

Dengan mengetahui alasan pekerja untuk berpartisipasi di dalam serikat pekerja, pihak manajemen dapat menampung dan menjadi fasilitator, karena partisipasi pekerja di dalam serikat pekerja tidak hanya di dasarkan pada alasan-alasan yang berkaitan dengan pekerjaan semata, juga didasarkan oleh alasan untuk bersosialisasi (rasa solidaritas dan dukungan moral). Hal ini menunjukkan bahwa pekerja menginginkan hubungan yang bersifat kekeluargaan. Manajemen dapat bekerjasama dengan serikat pekerja untuk mengadakan acara rekreasi bersama untuk lebih mendekatkan diri dengan pihak pekerja dan pada akhirnya pekerja merasa dihargai sebagai makhluk sosial. Dengan begitu ikatan emosional antara pekerja dengan perusahaan menjadi kuat. Karena mempunyai ikatan emosional dengan perusahaan, jika perusahaan mengalami masalah dengan pihak lain (pesaing ataupun pemerintah) pekerja melalui serikat pekerja akan membantu perusahaan.

Serikat pekerja harus menjaga dan bahkan harus meningkatkan kondisi lingkungan organisasinya dan harus dapat memposisikan dirinya sebagai wakil dan pekerja, dengan cara terus melakukan aktivitas-aktivitas yang berkaitan dengan kepentingan pekerja, seperti melakukan aksi bersama, pemberian dana pensiun, asuransi kesehatan, pemberian pelatihan dan pendidikan dan lain sebagainya, sehingga pekerja dapat berkonsentrasi terhadap pekerjaannya Agar aktivitas-aktivitas tersebut dapat berjalan dengan baik maka dibutuhkan partisipasi dan anggota serikat pekerja, teruta- 
ma dalam proses pengambilan keputusan, sehingga organisasi serikat pekerja menjadi dinamis dan dapat terus bertahan sebagai organisasi yang memberikan manfaat kepada anggotanya (pekerja). Serikat pekerja juga dapat mendirikan divisi usaha sendiri misalnya membentuk koperasi, yang hasilnya dapat digunakan untuk meningkatkan kesejahteraan anggotanya dan rasa memiliki dari anggota serikat pekerja terhadap organisasi serikat pekerja menjadi semakin besar.

Keterbatasan Penelitian. Penelitian ini memiliki keterbatasan yaitu hanya meneliti sebatas faktor-faktor yang mempengaruhi partisipasi pekerja di dalam serikat pekerja dan obyek penelitiannya hanya terbatas pada perusahaan-perusahaan yang berada di wilayah kerja kantor Departemen Tenaga Kerja Kota Semarang. Sedangkan proses perekrutan anggota serikat pekerja dan karakteristik dari masing-masing sektor usaha sebagai faktor pembeda dalam proses perekrutan anggota serikat pekerja tidak diteliti pada penelitian ini.

Agenda Penelitian yang Akan Datang. Untuk peneliti yang akan datang, bisa melakukan penelitian tentang faktor-faktor yang mempengaruhi perekrutan anggota serikat pekerja seperti shop steward, made contact my self, through a friend, recommended by management, direct approach from union head office, dan lain sebagainya dengan mengambil responden pekerja yang menjadi anggota serikat pekerja. Selain itu perlu dilihat karakteristik dari masing-masing sektor usaha sebagai faktor pembeda dalam proses perekrutan anggota serikat pekerja.

\section{DAFTAR PUSTAKA}

Anat Levy. 1990. Heterogenity and Union Membership Determination. Journal of Labor Research, Vol. 11, No. 1.

Aryee Samuel, and Yaw A. Debrah. 1997. Member's Participation in the Union: An Investigationof Some Determinants in Singapore. Human Relations, Vol.50, No.2.

Famham, David, and John Pimlott. 1995. Under- standing Industrial Relations. Singapore: Colset Private Limited.

Fiorito J, Gallagher, and Cynthia VF. 1988. Satisfaction with Union Representation. Industrial and Labor Relation Review, Vol.41, No. 2, January.

George, R, Gray, Donald W, Myers and Philips S, Myer. 1999. Cooperative Provisions in Labor Agreement, Monthly Labor Review, January.

Haberfeld, Y. 1995. Why Do Workers Join Unions? The Case of Israel. Industrial and Labor Relation Review, VoL 48, No.4, July.

Kelloway, Kevin, and Julian Barling. 1993. Member's Participation in Local Union Activities: Measurement, Prediction, and Replication. Journal of Applied Psychology, Vol.78, No2, pp: 262-279

Lucy A. Newton and Lynn M Shore. 1992. A Model of Union Membership, Instrumentality, Commitment, and Opposition, Academy of Management Review, Vol.17, No. 2, pp: 275-298.

Maryono dan Sri Sudarsi. 2000. Serikat Pekerja: Implikasinya terhadap Kebijaksanaan Manajemen, Semarang: Gema Stikubank, Januari.

Paul J, and Fiorito J. 1990. Associate Membership: Unionism or Consumerism, Industrial and Labor Relation Review, Vol. 43 No.2, January.

Paul Tolich dan Mark Harcourt, 1995, Why People Join Unions?. New Zealand Journal of Industrial Relations, Vol.24 No. 1.

Santoso, Singgih. 2000. Buku Latihan SPSS Statistik Parametrik. Jakarta: Elex Media Komputindo.

Sarosh, K, Daniel G, Kurt W. 1993. The Development of Members Attitudes toward Their Unions: Sweden and Canada, Industrial and Labor Relations Review, Vol. 46, No.3.

Sentanoe, Kertonegoro. 1999. Gerakan Serikat Pekerja. Yayasan Tenaga Kerja Indonesia. 
Shamad, Yunus. 1995. Hubungan Industrial di Indonesia. Jakarta: Bina Sumberdaya Manusia.

Shiddique, S.A. 1989. Industrial Relations in a Third World Setting, A Possible Model, The Journal of Industrial Relation, September.

Simamora, Henry. 1997. Manajemen Sumber Daya Manusia. Yogyakarta: STIE YKPN.

Sudono, Agus. 1997. Perburuhan dari Masa ke Masa, Jakarta: Pustaka Cudesindo.

Susanto, Joko. Ketegaran Upah Nominal untuk Turun: Kasus Upah Nominal Pekerja Produksi di Bawah Mandor pada Industri Besar dan Sedang Makanan Jadi, Bahan Pa- kaian, Karet, dan Plastik. Jurnal Ekonomi Pembangunan FE UMS. Vol. 10, No.1, Juni 2009, hal. 15 - 31. Surakarta: BPPE UMS.

Undang-undang Republik Indonesia, No. 21 Tahun 2000 Tentang Serikat Pekerja/Serikat Buruh, Jakarta: BP. Panca Usaha.

Undang-Undang Republik Indonesia, No.25, Tahun 1997 tentang Ketenagakerjaan, Jakarta: Sinar Grafika.

Uwiyono. 2000. Serikat Pekerja dan Peningkatan Hak-Hak Asasi serta Standar Ketenagakerjaan di Indonesia. Jurnal Pusat Studi Indonesia, Vol. 10.

Vedi R, Hadiz. 1996. Buruh Dalam Penataan Politik Awal Orde Baru. Prisma 7, Juli. 